\title{
Dinamika mazhab Shafi'i dengan cara Aceh: Studi tentang praktik mazhab di kalangan tokoh agama
}

\author{
Zulkarnain \\ IAIN Zawiyah Cot Kala Langsa \\ E-mail:emiyahya@gmail.com \\ DOI: 10.18326/ijtihad.v15i2.159-176
}

This study of the dynamics of shafi'ite school tried to uncover the diversity of the views regarding certain problems among the scholars of Shafi'ite school and between particular scholar and the imam Shafi'i himself. This focus deal with the dynamics existed in the Shafi'ite books. It should be done in the wise manner, for the dynamics it self was triggered by the certain situation and condition, different contexts, space, time, geography, circumstance and the condition of the nature that give birth to the different legal regulation. To understand the dynamics that occurred in those Shafi'ite books easily, we may borrow the rules of Arabic syntax namely 'ilm nahw, associated with the rule of istitsna' which consisted of six letters; illa, 'adaa, siwa, ghairu, khala and hasya. Those six letters have the same function that is the exemption, but the usage of each letter in the sentence has different rule in Arabic grammar. The dynamics rise dualism of Islamic jurisprudence in Aceh, in which the sharia court refer to the Compilation of Islamic Jurisprudence, while tengku (local muslim scholars) in Dayah refer to the turas book of Shafi'ite school. Slowly, the friction started between the legal decision issued by the sharia court and the fatwas issued by the tengku of Dayah (local Islamic boarding school), for instance, the issue of talaq, inheritance and other legal issues.

Penelitian tentang dinamika mazhab Syafi'i ini mencoba untuk mengungkap keragaman pandangan mengenai masalah-masalah tertentu di antara para ulama mazhab Syafi'i dan antara sarjana tertentu dan imam Syafi'i sendiri. Fokus kajian pada dinamika yang ada dalam buku-buku Syafi'i. Ini harus dilakukan dengan cara yang bijak, karena dinamika itu sendiri dipicu oleh situasi tertentu dan kondisi, konteks yang berbeda, ruang, waktu, geografi, keadaan dan kondisi alam yang melahirkan peraturan hukum yang berbeda. Untuk memahami dinamika yang terjadi dalam buku-buku Syafi'i dengan mudah, kita dapat meminjam aturan sintaks Arab yaitu 'ilm nahw, terkait dengan aturan istisna' yang terdiri dari enam huruf; illa', 'adā, siwa a, ghayr, khala dan hasya. Enam huruf memiliki fungsi yang sama yaitu pembebasan, 
namun penggunaan setiap huruf dalam kalimat memiliki aturan yang berbeda dalam tata bahasa Arab. Dinamika dualisme hukum Islam di Aceh, di mana pengadilan syariah mengacu pada Kompilasi hukum Islam, sementara tengku (ulama Muslim lokal) di Dayah mengacu pada buku tradisi dalam mazhab Syafi'i. Perlahan-lahan, gesekan mulai terjadi antara keputusan hukum yang dikeluarkan oleh pengadilan syariah dan fatwa yang dikeluarkan oleh tengku dari Dayah (pesantren setempat), misalnya, masalah talak, warisan dan masalah hukum lainnya.

Keywords: Compilation of Islamic law; Syafi'i; Ikhtilä;; Aceh

\section{Pendahuluan}

Realitas sosial, budaya dan hukum selalu terikat dengan ruang, waktu dan kondisi masyarakat.Hukum mengatur perilaku masyarakat dan sekaligus kebiasaan yang berlaku pada masyarakat berlaku juga sebagai hukum ('urf). Perlu disadari bahwa fikih merupakan hasil pemahaman melalui proses ijtihad. Ulama berinteraksi dengan lingkungannya, sehingga besar kemungkinan fikih terpengaruh oleh lingkungan di mana mujtahid bertempat tinggal.

Catatan sejarah mengabadikan bahwa Imam Shafi'i tidak menetap pada satu daerah saja.Ia dilahirkan di Desa Ghazza, Kota Asqalan pada tahun 150 H. Umur dua tahun ia dibawa kembali ke Mekah oleh ibu dan pamannya (Al-Asqalani, 1982: 17). Imam Shafi'i dibesarkan di Mekah, cukup lama belajar di Madinah, bekerja di Yaman sebagai Notulen (juru tulis) dan beberapa kali datang dan menetap di Baghdad, sehingga akhirnya menetap di Mesir sampai tahun wafatnya pada hari Kamis Ba'da Maghrib tanggal 30 Ra'jab tahun 204 H dan dimakamkan pada hari jum'at Ba'da Ashar di komplek Masjid Jami' di KarofahMesir di tanah perkuburan keluarga Abdullah bin Abdul Hakam. Ayahnya Idris bin Abbas dari Tabalah di Madinah dan wafat di Syam dalam sebuah perjalanan untuk suatu keperluan disana (Al-Asqalani, 1982: 38-41). Nasab Imam Shafi'i dari pihak ayah adalah sebagai berikut: Muhammad ibn Idris ibn Al-Abbas ibn 'utsman ibn Shafi'i ibn Saa'ib ibn 'U'baid ibn 'Abdi Yazid ibn Haasyim ibn Al-Muthalib ibn Abdi Manaf (Al-Shafi'i , 1980: 6).

Nasab Imam Shafi'i dari pihak ibu ada yang mengatakan Fatimah binti Ubaidillah bin Hasan bin Ali bin Abi Thalib bin Abdul Muthalib. Ada juga yang mengatakan ibu Imam Shafi'i adalah Habibah Al-Azdiyah dari Bani Azad bagian dari kabilah Al-Azad. Anas bin Malik meriwayatkan dari Nabi saw., Al-Azad Azadullah (berbekal dengan bekal dari Allah swt.). Hal ini menunjukkan kemuliaan kabilah azad di mana ibu Imam Shafi'i berasal (Al- 


\section{Dinamika mazhab Shafi'i dengan cara Aceh: Studi tentang praktik mazhab...(Zulkarnain )}

Shafi'i, 1980: 6). Argumen yang kedua inilah yang benar karena didasarkan kepada pengakuan Imam Shafi'i sendiri (Al-Subkhi, 1964: 193). Istri Imam Shafi'i adalah Humaidah binti Naafi' cucu dari khalifah Utsman bin Affan (Al-Subkhi, 1964: 193).

Imam Shafi'i memiliki empat orang anak, dua orang anak perempuan, yaitu Fatimah dan Zainab binti Muhammad bin Idris Al-Shafi'i dan dua orang anak laki-laki yang bernama Al-Hasan bin Muhammad bin Idris Al-Shafi'i meninggal pada saat masih bayi (Ibn Khalikan, 1971: 164). Anak Imam Shafi'i yang paling tua (sulung) bernama Abu 'Utsman Muhammad bin Idris Al-Shafi'i menjadi Qaadhi di Madinah dan Djazirah (W.240 H).

Di antara keistimewaan Imam Shafi'i adalah sebagai berikut:

1. Hafal Al-Qur'an umur 7 tahun dan hafal kitab Muwatha' Imam Malik umur 10 tahun.

2. Usia 15 tahun telah mendapat kepercayaan dari guru fikihnya Muslim ibn Khalid AlZanji untuk berfatwa sendiri (Al-Nawawi, 1984: 44).

3. Sangat menguasai kemurnian Zugh Arab (naluri bahasa Arab) sehingga disebut Hujjatul Luqhah. Hal ini dikarenakan Imam Shafi'i belajar bahasa Arab langsung dari Bani Huzail selama dua puluh tahun (Al-Nawawi, 1984: 51).

4. Digelar dengan Nashir Al-Hadits atau Nashir Al-Sunnah. Beliau juga pencetus Ilmu Mukhtatif Al-Hadits (Manshur, 1995: 2).

5. Banyak memberikan penafsiran terhadap ayat-ayat Ahkam meskipun tidak sempat menulis kitab tafsir secara khusus. Penafsiran beliau tentang ayat-ayat Ahkam ini telah dihimpun oleh Imam Al-Baihaqiy (W.458) dengan judul Ahkam Al-Qur'an Li Al-Imam Al-Shafi'i . Dikemudian hari kitab ini disusun ulang oleh Majdi Manshur dan diberi judul Tafsir Imam Al-Shafi'i (Al-Asqalani, 1982: 84).

6. Ahli ilmu Nasab atau silsilah keturunan para tokoh (Zahabi,1990: 218).

7. Pencetus ilmu Ushul Fikih (ketentuan dalam menggali hukum).

\section{Dinamika fikih mazhab Shafi'i di Aceh}

Fikih mazhab Syafii di Aceh telah ada dalam kurun waktu yang sangat lama, paling tidak dalam catatan Ibnu Bathutah pada saat melakukan perjalanan ke Tiongkok pada tahun 1345 M., Mazhab Syafii telah ada di Pasai pada masa raja Ahmad yang bergelar Sultan Malik alZahir II (1326M. - 1346 M.). Menurut Ibnu Bathutah, Sultan Malik az-Zahir sangat menguasai 
Mazhab Syafii dan ia juga bertemu dengan dua ulama bermazhab syafii di Pasai yang berasal dari siraz dan Isfahan (Hamka, 1994: 704).

Sebagaimana daerah Indonesia yang lain, fikih Mazhab Syafii telah mengakar di Aceh tetapi secara resmi fikih Mazhab Syafii baru menjadi rujukan Pengadilan Agama pada tahun 1953. Dengan demikian, sebenarnya sejak saat itu Mazhab Syafii telah menjadi "mazhab resmi negara". Hal ini dibuktikan dengan adanya surat instruksi Kementerian Agama tahun 1953 untuk menjadikan ke 13 kitab fikih syafiiyah sebagai bahan rujukan di Pengadilan Agama (Latyif, 1983: 79).

Ketiga belas kitab tersebut adalah: 1) Buhyat al-Mustarsyidin oleh Husein al-Baklawi; 2) Al-Faraidh oleh as-Syamsuri; 3) Fathul Muin oleh al-Mali Bary; 4) Al-Fiqh ala al-Mazahaib al-Arbaah oleh al-Jaziri; 5) Fathul Wahhab oleh al-Anshari; 6) Hasiyah Kifayatul Akhyar oleh al-Bajuri; 7) Mughni al-Muhtaj oleh al-Syarbini; 8) Qawanin as-Syariyah li al-Jazair alIndonesiayah al-Musamma irsyad Jawy al-Arham wajibat al-Qudaat wal ahkam oleh Sayid Shadaqan San'an (sejenis himpunan hukum acara); 9) Qawanin as-Syariyah oleh sayid Usman bin Yahya; 10) Qalyubi/Mahalli wa Syarhihi oleh Jalaludin al-Mahalli; 11) Zarqawi ala Tahrir oleh al-Syarqawi; 12) Targhib al-Musytaq; 13) Tuhfat al-Muhtaj oleh Ahmad Ibn Hajar alHaytami

Ke 13 kitab itu dikenal dengan sebutan al-Kurub al-Mu'tabarah yang penggunaannya didalam Pengadilan Islam Indonesia ditegaskan kembali dalam keputusan konferensi kementrian Agama ke 6 di Tretes Malang Jawa timur pada tanggal 25 sd 30 Juni 1955 (Mutahhar, 2003: 54).

Dasar pertimbangan hasil konferensi tersebut adalah untuk tegaknya kesatuan hukum, baik hukum materil maupun hukum formil dengan catatan sepanjang tidak bertentangan dengan Undang-undang. Kepada semua ketua Pengadilan Agama dianjurkan agar dalam memutuskan perkara yang menajdi kompetensinya menggunakan pedoman 13 kitab kitab fiqih syafiiyah seperti tersebut diatas. Penerapan tersebut berjalan sangan sinergis dengan kehidupan masyarakat aceh yang sangat kental warna syafiiyahnya. Karena sistem yang ditegakkan dalam penggalian hukum erat dengan metode bahsul masail yang biasa diterapkan pada dayah-dayah atau pesantren di Aceh, dan para santri tidak merasa asing dengan itu. Namun susana tersebut berubah, karena sejak 1987 aceh sebagaimana wilayah indonesia 


\section{Dinamika mazhab Shafi'i dengan cara Aceh: Studi tentang praktik mazhab...(Zulkarnain )}

lainnya mengalami perubahan yang signifikan di mana para hakim agama akhirnya didominasi oleh lulusan IAIN (Feiilland, 1991: 351).

Perubahan itu akhirnya melahirkan dualisme hukum Islam di Aceh. Di mana mahkamah syariyah merujuk kepada kompilasi hukum Islam sedangkan tengku-tengku di dayah tetap merujuk kepada kitab-kitab fikih turas Mazhab Syafii. Secara perlahan-lahan mulai timbul friksi antara keputusan-keputusan Mahkamah Syariyah dengan fatwa-fatwa tengku di Dayah. Contoh kongkrit berkaitan dengan persoalan ini, misalnya talak tiga sekali ucap, di mana dalam kompilasi hukum Islam hanya dihitung satu talak sedangkan dalam kitab-kitab fikih syafiiyah dihitung tiga talak sekaligus.

Begitu juga dalam persoalan pembagian warisan di mana kompilasi hukum Islam membolehkan anak angkat menerima warisan sedangkan fikih syafiiyah tidak membolehkannya. Contoh friksi lainnya adalah persoalan talak baru dianggap sah oleh kompilasi hukum Islam (pasal 129) jika dilakukan di pengadilan dan dimuka hakim sedangkan fikih syafiiyah tidak demikian. Di Aceh kompilasi hukum Islam yang disusun berdasarkan keputusan Mahkamah Agung dan Mentri Agama Nomor 017/KMA/1985 tentang penunjukan pelaksaaan proyek pembangunan hukum Islam melalui jurisprudensi tanggal 21 Maret 1985 menyangkut tiga kategori materi hukum dengan 229 pasal meliputi: 1) Hukum perkawinan 170 pasal, 2) Hukum waris (wasiat dan hibah) 44 pasal, 3) Hukum wakaf 14 pasal.

Peraturan yang telah disahkan presiden Republik Indonesia tahun 1991 tersebut adalah sesuatu yang "menggelisahkan" bagi umat Islam di Aceh menyangkut penerapan syariat Islam secara kaffah. Hal ini dikarenakan adanya dualisme antara kompilasi hukum Islam yang diterapkan Mahkamah Syariyah dan fikih syafiiyah yang diterapkan oleh dayah dan Majelis Permusyawaratan Ulama Aceh. Oleh karenanya untuk mengurangi realitas friksi tersebut, melalui tulisan ini disarankan adanya peninjauan ulang terhadap kompilasi hukum Islam minimal dalam konteks ke-Aceh-an.

\section{Peran Dayah Tanoh Abey sebagai Dayah Shafi'iyyah tertua di Aceh}

Jika kita membaca catatan sejarah tentang dayah Shafi'i yyah tertua yang masih terus eksis sampai hari ini di Aceh, maka Dayah Tanoh Abey adalah satu-satunya dayah yang masih 
aktif dengan jumlah peninggalan Kutubkhanah (perpustakaan) sekitar seribu kitab turats (klasik). Dayah Tanoh Abey merupakan dayah Shafi'i yyah yang didirikan sejak abad ke-17 pada zaman pemerintahan Sultan Iskandar Muda Meukuta Alam.

Dalam catatan yang ditemukan di Dayah Tanoh Abey, pada zaman pemerintahan Sultan Iskandar Muda Meukuta Alam (1016-1045 H/1607-1636 M) datang dari Baghdad (Iraq) tujuh ulama bersaudara yang tertua bernama Firus al-Baghdadi, empat di antaranya bermukim di wilayah Sagoe XXII Mukim yang diperintah oleh uleebalang yang bergelar Teuku Panglima Polem Sri Muda Perkasa. Sementara yang tiga orang lagi bermukim di Tiro, Pidie, dan Pasai (Aceh Utara) (Hasjmy, 1997: 3).

Firus al-Baghdadi sebagai ulama tertua dari tujuh ulama yang datang dari Baghdad tersebut membangun pusat pendidikan madzhab Shafi'i di Gampong Tanoh Abey di bawah kekuasaan kerajaan Aceh Darussalam. Dayah ini terus berkembang mencapai puncaknya hingga pada masa pemerintahan Sultan Alaidin Mughaiyat Syah Iskandar Tsani (1045-1050 H/1636-1641 M) dan masa pemerintahan Sultanah Ratu Tajul Alam Safiatuddin (10501086 H/1641-1675 M). Dayah Tanoh Abey dalam perkembangannya diteruskan oleh anakanak Firus al-Baghdadi, khususnya anak sulungnya yaitu Syekh Nayan Firusi al-Baghdadi.

Syekh Nayan Firusi al-Baghdadi di samping belajar agama dari ayahnya juga belajar ke Dayah Leupue di Peunayong Banda Aceh salah satu dayah tertua di kerajaan Aceh Darussalam pada masa itu yang dipimpin oleh Syekh Daud (Baba Daud) al-Rumiy karena ia berasal dari kerajaan Turki Usmaniyyah. Syekh Nayan mempunyai seorang putra, yaitu Syekh Abdul Hafidh yang menjadi penerus Dayah Tanoh Abey sepeninggal Syekh Nayan. Pada masa Syekh Nayan Dayah Tanoh Abey baru dibuka di sebuah lokasi yang bernama Tuwi Ketapang dekat dengan Krueng Aceh (Banda Aceh) dan Dayah Tanoh Abey yang baru ini digunakan untuk santri putra sedangkan Dayah Tanoh Abey lama di era Syekh Abdul Hafidh digunakan untuk santri putri. Syekh Abdul Hafidh al-Baghdadi di samping sebagai Teungku Chik Dayah Tanoh Abey, oleh Teuku Panglima Polem Sri Muda Perkasa diangkat menjadi Kadhi Rabbul Jalil Sagoe XXII Mukim.

Selanjutnya Dayah Tanoh Abey dilanjutkan oleh Syekh Abdurrahim Hafidh al-Baghdadiy, pada era beliau Kutubkhanah(perpustakaan) ditingkatkan. Selanjutnya berturut-turut Dayah Tanoh Abey dipimpin oleh Syekh Muhammad Saleh al-Baghdadiy, Syekh Abdul Wahab 
Saleh al-Baghdadiy, Syekh Muhammad Said al-Baghdadiy dan Tgk. Muhammad Ali alBaghdadiy.

Pada saat Indrapuri direbut Belanda, maka ibukota kerajaan dipindah ke Keumala di wilayah Pidie. Teungku Chik Dayah Tanoh Abey pada masa itu yaitu Tgk. Muhammad Ali al-Baghdadiy sudah memprediksi bahwa Dayah Tanoh Abey akan dihancurkan Belanda seperti dayah-dayah Shafi'i yyah lainnya seperti Dayah Lamtirah, Dayah Indrapuri, Dayah Rumpet dan Dayah Lam Diran. Oleh karenanya Tgk. Muhammad Ali al-Baghdadiy menyelamatkan 10.000 kitab turats yang ada di Dayah Tanoh Abey tersebut dengan cara dititipkan kepada orang-orang kampung yang dipercaya dan ada juga yang disembunyikan di daerah pedalaman Tangse di Pidie.

Pada tanggal 19 Sya'ban 1318 H (12 Desember 1980 M) Tgk. Muhammad Ali ditawan Belanda dan ditahan di penjara kampung Keudah, selanjutnya dibuang ke Betawi, selanjutnya dipindah ke Surabaya di Jawa Timur, kemudian dibuang ke Manado di Sulawesi Utara. Setelah lima tahun masa pembuangan, maka Tgk. Muhammad Ali al-Baghdadiy dipulangkan kembali ke Aceh pada tanggal 18 Sya'ban 1323 H (17 Oktober 1905 M). Setelah berjihad dan bergerilya di hutan dan lembah, setelah ditawan, dipenjara dan dibuang dari tanah kelahirannya selama lima tahun dan setelah membangun kembali Dayah Tanoh Abey warisan leluhurnya, maka pada tahun 1389 H (1969 M) Tgk. Muhammad Ali bin Muhammad Said al-Baghdadiy wafat (Hasjmy, 1997: 12).

Kitab-kitab dalam Kutubkhanah (perpustakaan) Dayah Tanoh Abey yang dapat diselamatkan dari keganasan "perang kolonial di Aceh", tidak sampai dua ribu buah.

Salah seorang putra Teungku Chik Tanoh Abey Muhammad Ali, yang bernama Tgk. Muhammad Dahlan al-Firusi (Tgk. Muhammad Dahlan bin Muhammad Ali al-Baghdadiy) sekarang bertindak sebagai “pewaris" Dayah Tanoh Abey dan tugas utamanya memelihara dan membina kembali Kutubkhanah yang sudah hampir musnah itu.

Tgk. Muhammad Dahlan yang masih muda telah menyediakan dirinya untuk menjadi "khadam" bagi sebuah "khazanah Islam" yang sudah begitu berjasa. Dengan amat ramah, beliau menerima tamu-tamu yang datang, kebanyakan para sarjana, baik dari dalam negeri maupun dari luar negeri. Mereka kesana untuk menyaksikan sebuah warisan yang dapat menceritakan bahwa pada suatu waktu yang sudah lama lampau, Tanah Aceh sudah pernah 
menjadi pusat kegiatan ilmu dan kebudayaan Islam di Asia Tenggara.

Dalam Kutubkhanah Dayah Tanoh Abey sekarang masih dapat kita saksikan lebih seribu buah naskah kitab tulisan tangan, baik dalam bahasa Melayu maupun dalam bahasa Arab; baik karangan para ulama Aceh/Melayu maupun karangan para ulama Arab, Turki, Parsi dan sebagainya. Di samping itu, masih dapat kita jumpai beberapa naskah Alquranul Karim yang ditulis tangan dengan nilai kaligrafi yang amat tinggi; salah satu di antaranya tulisan tangan Teungku Chik Tanoh Abey Abdul Wahab sendiri.

Juga dalam Kutubkhanah Dayah Tanoh Abey, masih dapat kita temui sarakata-sarakata (dokumen) penting, baik yang berupa surat keputusan, surat perjanjian maupun surat-surat kepada Teungku Chik Tanoh Abey; di antaranya ada surat dari Turki, dari Mekkah dan sebagainya. Hal ini pun memberi isyarat kepada kita untuk mengakui bahwa para Teungku Chik Tanoh Abey adalah ulama-ulama yang juga ahli-ahli administrasi yang cermat.

Khazanah Islam yang seperti di Kutubkhanah Dayah Tanoh Abey mungkin tidak terdapat lagi di seluruh Asia Tenggara, seperti yang dikesankan oleh beberapa orang sarjana yang berkunjung kesana, baik sarjana Indonesia maupun sarjana luar negeri.

Menurut mereka, naskah-naskah tua bertulisan tangan yang telah berusia ratusan tahun, baik dalam bahasa Melayu maupun dalam bahasa Aceh, sulit untuk didapati sekarang dan besar manfaatnya untuk diteliti dan dipelajarinya (Hasjmy, 1997: 12-13).

Lebih menarik, para sarjana yang sempat menelaah sejumlah kitab dalam Kutubkhanah Dayah Tanoh Abey, menyimpulkan bahwa para Teungku Chik yang membina dan memimpin Dayah Tanoh Abey sejak permulaan adalah ulama ahli sunnah wal jama'ah penganut madzhab Shafi'i, tetapi Dayah Tanoh Abey telah membuktikan terbukanya keleluasaan pintu ilmu dengan didapatkannya juga beberapa kitab yang ditulis oleh ulama Mu'tazilah dan Syi' ah, bahkan kitab-kitab para ulama yang menganut aliran wahdatul wujud, seperti ibnul Arabi, Hamzah Fansuri dan Syamsuddin Sumatrani ditemukan kitabnya di Dayah Tanoh Abey sebagai upaya memperluas khazanah dan wawasan semata.

\section{Ulama Shafi'iyyah Aceh dan perang Cumbok}

Aceh pernah mengalami perang saudara yang sangat memilukan dan membekas secara mendalam pada setiap lubuk hati orang Aceh. Perang saudara di Aceh tersebut terkenal 
dengan nama Perang Cumbok. Disebut perang Cumbok karena peristiwa perang saudara tersebut berpusat di Cumbok - Pidie. Meskipun perang saudara itu berlangsung tidak lama, hanya kurang-lebih beberapa bulan saja (akhir 1945 sampai dengan awal 1946) tetapi rekam jejak peperangan itu di dalam hati orang Aceh sangat membekas.

Pada dasarnya perang Cumbok terjadi karena kesalahpahaman didalam komunikasi dan penafsiran yang berbeda antara kaum ulama dan uleebalang (hulubalang/bangsawan) terhadap Proklamasi Indonesia pada tanggal 17 Agustus 1945 (Hasjmy, 1997: 96). Perang Cumbok dikalangan masyarakat Aceh lebih dikenal sebagai peperangan antara para ulama di satu pihak dengan kaum bangsawan (hulubalang) di pihak yang lain. Karena sejak zaman penjajahan Belanda kedua komponen ini sudah sering berseberangan. Para hulubalang dituduh sering mengkhianati perjuangan para ulama dan pejuang Aceh dalam menentang segala bentuk intimidasi kolonial Belanda. Begitu juga pasca Proklamasi 17 Agustus 1945, hulubalang dianggap menginginkan kembalinya kekuasaan Belanda di Aceh (Hasjmy, 1997: 96).

Secara prinsip, sebenarnya tidak semua ulama setuju dengan perang Cumbok ini. Salah seorang tokoh kunci ulama madzhab Shafi'i Aceh, yaitu Tgk. Syekh Abu Krueng Kalee adalah salah seorang ulama yang tidak menyetujui peperangan tersebut. Beliau yang diutus pihak pejuang Aceh di Kutaraja untuk bertemu Teuku Daud Cumbok agar mau berdamai. Tetapi pertemuan itu dipandang gagal karena Teuku Daud Cumbok menolak ajakan damai tersebut, dengan alasan bahwa ia tidak mungkin mundur setelah nama baik hulubalang tercemar akibat tuduhan-tuduhan yang belum terbukti (Hasjmy, 1997: 97).

Menurut penuturan Tgk. H. Syekh Marhaban (Hasjmy, 1997: 97), menjelang terjadinya perang Cumbok, dalam suatu rapat di mana para ulama telah setuju dengan peperangan itu, Tgk. Syekh Abu Krueng Kalee menyatakan tidak setuju dengan alasan dalil ayat Alquran surat al-Hujarat [49] ayat 9 sebagai berikut:

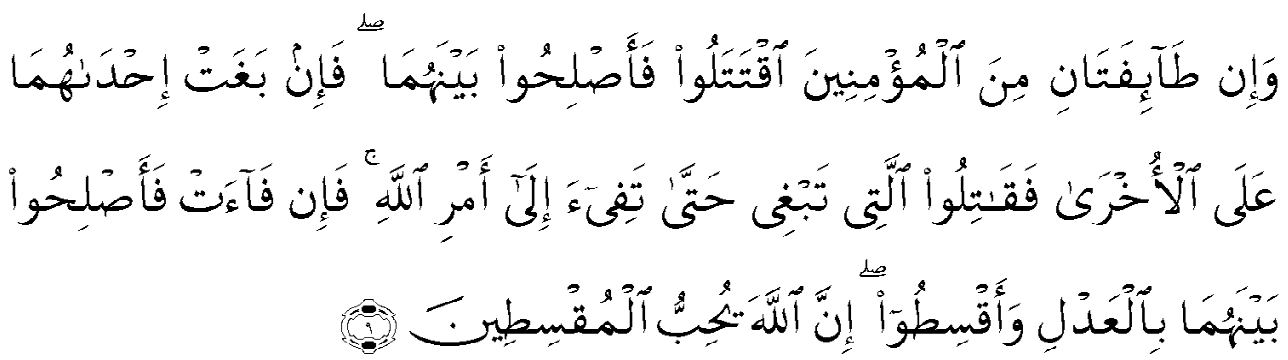


"Dan kalau ada dua golongan dari mereka yang beriman itu berperang hendaklah kamu damaikan antara keduanya! Tapi kalau yang satu melanggar perjanjian terhadap yang lain, hendaklah yang melanggarperjanjian itu kamu perangi sampai kembali pada perintah Allah. Kalau dia telah kembali kepada perintah Allah, damaikanlah antara keduanya menurut keadilan, dan hendaklah kamu berlaku adil; sesunggubnya Allah mencintai orang-orang yang berlaku adil”.

Penolakan Tgk. Syekh Abu Krueng Kalee yang mengedepankan ayat Alquran dan haditshadits Nabi saw., membuat tidak ada yang berani mengambil resiko untuk memulai perang. Akhirnya rapat memutuskan untuk mengutus Tgk. Syekh Abu Krueng Kalee untuk menemui panglima pasukan Hulubalang Teuku Daud Lamlo, juga dikenal dengan sebutan Teuku Daud Cumbok yang bertempat tinggal di Kuta Bakti dengan satu misi yaitu berdamai. Pada saat itu Tgk. Syekh Abu Krueng Kalee ditemani seorang ulama madzhab Shafi’i lain yaitu Tgk. Abdullah Lhok Kajhu (Abu Sigli) setelah dijelaskan maksud dan tujuan kedatangan Tgk. Syekh Abu Krueng Kalee, akhirnya Teuku Daud Cumbok menjawab:’'Teungku nyang Guree lon tuan. Lon ke a ditrom le' si Daud lam leubob, hanjeut lon teubit lei. Jadi hanjeut lon surut le'. Aleuhnyan, lon pib ureung Aceh. Nyawong pih saboh, hana dua” (Hasjmy, 1997: 98). (Teungku, guru saya. Saya sudah ditendang ke dalam lumpur oleh si Daud (maksudnya Tgk. Daud Beureueh), pimpinan Persatuan Ulama Seluruh Aceh (PUSA), jadi tidak mungkin keluar lagi. Lagi pula saya orang Aceh. Nyawa hanya satu, tidak ada dua). Kemudian Tgk. Syekh Abu Krueng Kalee kembali bertanya: "Nyan nyang Teuku pengah kabeeh neupikee?”. (Yang Teuku katakan itu apa sudah dipikirkan dengan matang?). Teuku Daud Cumbok menjawab: "Ka” (sudah). Tgk. Syekh Abu Krueng Kalee kembali bertanya: "Meunyoe lon preh, lon bi watee neupikee, peu neupikee lom atau han?"(Jika saya tunggu untuk beri waktu Teuku berpikir, apa Teuku mau?) Jawab Teuku Daud Cumbok: "Hana lon pikee le" (Tidak perlu saya pikir lagi). Tgk. Syekh Abu Krueng Kalee kembali bertanya: 'Lon tanyong sigoe tenk, kabeeh neupikee?" (Saya ulang sekali lagi, apa sudah dipikir dengan matang-matang?). Teuku Daud Cumbok menjawab: "Ka abeeh" (sudah) (Hasjmy, 1997: 98-99).

Dampak dari kegagalan misi perdamaian yang diemban oleh ulama besar mazhab Shafi'i ini, akhirnya perangpun tidak terelakkan. Antara saudara dari dua kubu yang berbeda saling berhadap-hadapan di medan perang. Perang Cumbok ini berakhir pada bulan Januari 1946 setelah pasukan dari pihak ulama dengan kekuatan rakyat berhasil menggempur dan mengalahkan pasukan Cumbok yang dipimpin oleh Teuku Daud Cumbok di tempat pertahanannya yang terakhir yaitu di Lamlo Kuta Bakti - Pidie. 
Dinamika mazhab Shafi'i dengan cara Aceh: Studi tentang praktik mazhab...(Zulkarnain )

\section{Peran ulama Shafi'iyyah Aceh pada era penjajahan dan kemerdekaan}

Jika berbicara tentang perlawanan terhadap penjajahan Jepang di Aceh, tidak lengkap jika belum memasukkan kiprah ulama-ulama Shafi'i yyah di dalam perjuangan mengusir Jepang dari Aceh. Dan nama ulama Shafi'iyyah paling populer dalam persoalan ini adalah; Tgk. Abdul Jalil Cot Plieng. Karena kegigihannya melawan penjajahan Jepang di Aceh Utara, tepatnya di Cot Plieng - Bayu, beliau bersama dengan 105 orang pasukannya gugur sebagai syuhada setelah digempur pasukan Jepang dalam kawasan masjid Cot Plieng - Bayu di Aceh Utara.

Pasca kemerdekaan Republik Indonesia, yang diproklamirkan pada tanggal 17 Agustus 1945, tidak berarti Indonesia telah benar-benar terbebas dari penjajahan asing. Suasana keamanan nasional Indonesia pada masa itu masih dalam keadaan sangat labil karena Inggris sebagai salah satu negara sekutu Belanda masih terus diboncengi untuk dapat kembalinya tentara Belanda menguasai Indonesia. Tentara sekutu dengan terang-terangan diboncengi oleh NICA (militer Belanda) untuk menguasai wilayah Jawa, bahkan Sumatera Utara dan Pangkalan Berandan yang berada di perbatasan Aceh juga sudah mulai dimasuki tentara NICA yang dibonceng oleh Inggris.

Melihat situasi yang sangat genting itu, ulama-ulama Aceh yang mayoritas bermadzhab Shafi'i, pada tanggal 15 Oktober 1945 mengeluarkan "Makloemat Oelama Seloeroeh Atjeh". Inti maklumat ini adalah berisi dukungan penuh masyarakat Aceh terhadap kemerdekaan Republik Indonesia yang telah diproklamirkan oleh Presiden Soekarno. Seluruh ulama Aceh yang mayoritas bermadzhab Shafi'i memandang bahwa perjuangan mempertahankan kemerdekaan Republik Indonesia adalah sama dengan perjuangan suci yang disebut perang sabil.

Maklumat ulama seluruh Aceh tersebut dinyatakan oleh empat ulama besar Aceh madzhab Shafi'i, yaitu Tgk. H. M. Hasan Krueng Kalee, Tgk. H. Dja'far Siddik Lamjabat, Tgk. Ahmad Hasballah Indrapuri dan Tgk. Muhammad Daud Beureueh. Di samping dinyatakan oleh empat ulama besar Aceh yang bermadzhab Shafi'i, maklumat tersebut juga diketahui oleh Komite Nasional Indonesia Daerah Aceh (KNIDA) yang disetujui oleh Tuwanku Mahmud serta diketahui oleh Teuku Nyak Arief selaku Residen Aceh.

Tgk. Syekh Abu Krueng Kalee selaku lokomotif madzhab Shafi'i yang dominan di wilayah pantai utara Timur Aceh juga membuat maklumat bersama atas nama pribadinya 
pada tanggal 25 Oktober 1945 yang ditujukan kepada seluruh ulama Aceh pada masa itu. Seruan tersebut ditulis dalam tulisan Arab-Jawi (Arab-Melayu) yang dicetak oleh Markas Daerah Pemuda Republik Indonesia (PRI) dengan surat pengantar yang ditandatangani oleh Ali Hasjmy selaku Ketua Umum Organisasi Pemuda Republik Indonesia.

Manfaat besar dari kedua maklumat tersebut sangat dirasakan bagi seluruh rakyat Aceh dan pemerintah Republik Indonesia sehingga pada saat Presiden Republik Indonesia yang pertama, Bung Karno, mengunjungi Aceh pada bulan Juni 1948, beliau menegaskan: "Bahwa Aceb dan segenap rakyat Aceh adalah modal pertama bagi kemerdekaan Republik Indonesia”.

Efek kejut maklumat ulama Aceh yang dinyatakan oleh para pemuka madzhab Shafi'i Aceh tersebut sangat luar biasa. Masyarakat Aceh memandang maklumat tersebut sebagai suatu aba-aba komando yang jelas untuk menunaikan janji bakti kepada Allah SWT. membela negara dari penjajahan asing yang kafir. Maklumat ulama seluruh Aceh itu bagi masyarakat bernilai jihad akbar, perang suci yang membawa pada predikat ukhrawi tertinggi yaitu syahid yang balasannya adalah surga.

Langkah konkrit dari maklumat ulama seluruh Aceh tersebut adalah lahirnya berbagai front perjuangan rakyat Aceh. Di antaranya lahirlah Barisan Mujahidin pada tanggal 17 Nopember 1945 sebagai kesimpulan dari rapat besar di Masjid Tiro di Pidie. Konon rapat tersebut dihadiri kurang-lebih 600 orang ulama dan tokoh masyarakat Pidie yang dipimpin oleh Tgk. Umar Tiro, cucu dari Teungku Chik Muhammad Saman Ditiro yang juga merupakan murid dari lokomotif madzhab Shafi'i yaitu Tgk. H. Muhammad Hasan Krueng Kalee. Barisan Mujahidin yang baru dibentuk itu dibantu oleh dua orang Bendahara, yaitu Tgk. H. Syekh Marhaban Hasan Krueng Kalee, anak Tgk. H. Muhammad Hasan Krueng Kalee dan Teuku Muhammad Amin.

Di Banda Aceh, pada tanggal 23 Nopember 1948 dibentuk Barisan Hizbullah yang dipimpin oleh Tgk. Muhammad Daud Beureueh dengan wakilnya Tgk. H. Ahmad Hasballah Indrapuri dengan sekretaris umumnya Teuku Muhammad Amin, sekretaris I, Tgk. Marhaban Krueng Kalee dan Tgk. Sulaiman Mahmud Ulee Kareng sebagai sekretaris II. Dan terhitung 1 Desember 1945 untuk menjaga keutuhan di antara para pejuang dan tokoh-tokoh ulama maka Barisan Hizbullah mengubah namanya menjadi Laskar Mujahidin yang dilengkapi dengan Barisan Wanita Muslimat (Laskar Mujahidat) yang dibentuk pada tanggal 21 Februari 
Dinamika mazhab Shafi'i dengan cara Aceh: Studi tentang praktik mazhab...(Zulkarnain )

1946 (Fahmi, 2010: 92).

Dayah Meunasah Blang yang dipimpin oleh Tgk. Syekh Abu Krueng Kalee menjadi Markas Besar Laskar Mujahidin dan mengirimkan lima puluh santri mujahidin untuk berperang ke Medan Area dalam hal ini Besitang dan Pangkalan Berandan di Sumatera Utara. Sebelumnya ulama-ulama madzhab Shafi'i di Aceh telah lebih dahulu mengirimkan tiga batalion untuk menghadapi Belanda di peperangan Medan Area, yaitu Batalion Husein Yusuf, Batalion Kolonel Muhammad Nurdin yang merupakan murid dan sekaligus anak angkat Tgk. Syekh Abu Muhammad Hasan Krueng Kalee dan Batalion Teuku Hamzah (Fahmi, 2010: 93).

Perjuangan ulama Shafi'iyyah menghadapi agresi militer Belanda yang membonceng melalui tentara Inggris membutuhkan biaya yang cukup besar. Oleh karenanya pada tanggal 2 Agustus 1947 di Kutaraja (Banda Aceh) dibentuk Badan Perbendaharaan Perang Sabil yang diputuskan melalui Keputusan Dewan Pertahanan Daerah Aceh No. 7/DPD dibawah kepemimpinan Tgk. Syekh Hasballah Indrapuri dan Tgk. Abdurrahman Meunasah Meucap Geulumpang Dua. Melalui Badan ini segala keperluan perjuangan Laskar Mujahidin yang dipimpin oleh tokoh-tokoh ulama Shafi'iyyah di Aceh dipasok.

\section{Lokomotif mazhab Shafi'i di Aceh}

Ada dua lokomotif besar dalam pengembangan mazhab Shafi'i di Aceh, yang satu dipimpin oleh Tgk. Syekh Muda Waly al-Khalidi al-Naqsyabandi dan Tgk. Haji Muhammad Hasan Krueng Kalee. Tgk. Syekh Muda Wali al-Khalildi adalah seorang ulama yang dilahirkan di desa Blang Poroh, Kecamatan Labuhan Haji Kabupaten Aceh Selatan pada tahun 1917. Beliau adalah putra bungsu dari Syekh H. Muhammad Salim bin Malin Palito. Ayahnya berasal dari Batu Sangkar, Sumatera Barat. Ayah Syekh Muda Wali datang ke Aceh sebagai da’i. Sebelumnya paman beliau yang masyhur dipanggil masyarakat Labuhan Haji dengan sebutan Tuanku Pelumat bernama asli Syekh Abdul Karim telah lebih dahulu menetap di Labuhan Haji.

Syekh Muda Wali belajar Alquran dan kitab-kitab kecil tentang tauhid, fikih dan dasar ilmu bahasa Arab dari ayahnya. Ia juga masuk sekolah Volks-School yang didirikan oleh Belanda. Setamatnya dari Volks-School beliau dimasukkan ke pesantren di ibukota Labuhan Haji yaitu Pesantren Jamia'ah al-Khairiyah yang dipimpin oleh Tgk. Muhammad Ali yang dikenal oleh masyarakat dengan panggilan Tgk. Lampisang dari Aceh Besar, sambil beliau 
sekolah di Vervolg School. Empat tahun kemudian beliau dimasukkan ke Pesantren Bustanul Huda di ibukota Kecamatan Blang Pidie yang dipimpin seorang ulama besar, yaitu Tgk. Syekh Mahmud.

Di pesantren ini beliau mulai mempelajari kita-kitab ulama Shafi'iyyah seperti I'anat alTalibin, Tabrir dan al-Mahally dalam bidang fikih Shafi'iyyah, dan mempelajari kitab Alfiyah dan Ibnu 'Aqil dalam bidang Nabwu dan Sharaf. Beliau juga pernah belajar kepada Tgk. Hasan Krueng Kalee, Tgk. Syekh Hasballah Indrapuri dan sekaligus mengajar di dayah milik Tgk. Syekh Hasballah Indrapuri. Kemudian Tgk. Syekh Muda Waly dikirim oleh Teuku Hasan Gelumpang Payung untuk belajar ke Sumatera Barat, yaitu ke sekolah Normal Islam School yang dipimpin oleh ustadz Mahmud Yunus, alumnus al-Azhar, Mesir.

Setelah tiga bulan di Normal Islam School beliau keluar dan kemudian atas saran Tgk. Ismail Ya'kub beliau menetap di Padang dan tidak pulang ke Aceh. Di Kota Padang ini beliau kenal dengan Syekh Haji Khatib Ali ualama besar ahlussunnah wa al-Jama'ah dan bermazhab Shafi'i, murid dari Syekh Ahmad Khatib di Mekkah. Dari pertemuan tersebut, Syekh Muda Waly dinikahkan dengan salah seorang keluarga Syekh Haji Khatib Ali, bernama Hajjah Rasimah yang kelak melahirkan Syekh Prof. Muhibbuddin Waly. Beliau juga berkenalan dengan Syekh Muhammad Jamil Jaho yang kemudian menikahkan putrinya bernama Hajjah Rabi'ah dengan Syekh Muda Waly yang kemudian lahirlah Syekh H. Mawardi Ali. Akhirnya Syekh Muda Wali belajar ke Mekkah, berguru kepada Syekh Ali al-Maliki, pengarang kitab Hashiyah al-Ashbah wa al-Nază̄ir.

Sepulangnya dari belajar di Mekkah, beliau mengambil Tariqat Naqsyabandi dari ulama besar tarekat yaitu Syekh Abdul Ghani al-Kanfari, bertempat di Batu Bersurat - Kampar Bangkinang. Pada saat Jepang akan masuk ke Sumatera Barat, Syekh Muda Wali memutuskan untuk kembali ke Aceh. Lebih kurang akhir tahun 1939 beliau kembali ke Aceh Selatan menggunakan perahu layar. Di beberapa pesantren yang beliau dirikan di Aceh, beliau memberinya nama yang berbeda-beda.

Pesantren pertama diberi nama Darul Muttaqin, kedua Darul Arifin, Ketiga Darul Muta'allimin, Keempat Darul Salikin, kelima Darul Zahidin dan keenam Darul Ma'la. Dari keenam dayah inilah Tgk. Syekh Muda Waly akhirnya memiliki murid yang menyebar ke wilayah barat selatan dan sebahagian pantai utara dan timur Aceh. Murid-muridnya yang 
Dinamika mazhab Shafi'i dengan cara Aceh: Studi tentang praktik mazhab...(Zulkarnain )

terkenal di antaranya adalah Tgk. Haji Abdullah Hanafiah Tanoh Mirah - Biruen, Tgk. Abdul Aziz bin Salih pimpinan Pesantren Ma'had al-Ulum Diniyah Islamiyah Samalanga, Tgk. Muhammad Amin Blang Bladeh, Tgk. Muhammad Amin Arbi Tanjungan - Samalanga, Tgk. Daud Zamzamiy Aceh Besar, Tgk. Syekh Sihabuddin Syah (Abu Keumala), Tgk. Adnan Mahmud Bakungan, Tgk. Muhammad Isa Peudada, Tgk. Abu Bakar Sabil Meulaboh, dan masih banyak yang lainnya.

Syekh Muda Waly wafat pada tanggal 11 Syawal 1381 Hijriyah (20 Maret 1961 M), tepat pada pukul 15.30 wib hari Selasa dan dimakamkan di komplek Dayah Labuhan Haji. Beberapa pesantren besar di Aceh yang meneruskan pandangan Syekh Muda Waly yang bermazhab Shafi'i terdiri atas:

1. Pesantren LPI MUDI MESRA Samalangan. Dipimpin oleh Tgk. H. Hasanoel Basri (Abu Mudi).

2. Pesantren al-Madinatud Diniyah Babussalam Blang Bladeh. Dipimpin oleh Syekh Muhammad Amin (Abu Tumin).

3. Pesantren Malikul Saleh Panton Labu. Dipimpin oleh Syekh Ibrahim Bardan (almarhum Abu Panton).

4. Pesantren Darul Huda Lhueng Angen - Lhok Nibong. Dipimpin oleh Syekh Abu Daud

5. Pesantren Darul Munawwarah Kuta Krueng. Dipimpin oleh Tgk. Haji Usman Kuta Krueng.

6. Pesantren Darul Ulum Tanoh Mirah - Biruen. Dipimpin oleh Tgk. Muhammad Waly.

7. Pesantren Raudatul Ma'arif Cot Trueng-Aceh Utara. Dipimpin oleh Tgk. H. Muhammad Amin.

8. Pesantren Darul Huda Paloh Gadeng - Aceh Utara. Dipimpin oleh Tgk. Mustafa Ahmad.

9. Pesantren Ashabul Yamin Bakongan Aceh Selatan. Dipimpin oleh Syekh Marhaban Adnan.

10. Pesantren Ruhul Fata Seulimum - Aceh Besar. Dipimpin oleh Tgk. H. Mukhtar Lutfi.

11. Pesantren Serambi Mekkah Meulaboh - Aceh Barat. Dipimpin oleh Syekh Muhammad Nasir Lc.

12. Pesantren Bahrul Ulum Diniyah Islamiyah (BUDI) - Lamno Aceh Jaya. Dipimpin oleh Tgk. H. Asnawi Ramli.

13. Pesantren Yayasan Dayah Ulee Titi - Aceh Besar dipimpin Tgk. Syekh Atha'illah. 
Kesemua pesantren di atas bermazhab Shafi'i dan berada di bawah lokomotif besar Tgk. Syekh Muda Waly, karena semua pendiri pesantren-pesantren tersebut adalah muridmurid Syekh Muda Waly. Adapun lokomotif mazhab Shafi'i yang kedua di Aceh adalah Tgk. Haji Muhammad Hasan Krueng Kalee. Seorang ulama besar Aceh yang hidup pada kurun waktu 1886-1973 M. Jika Tgk. Syekh Muda Waly memiliki murid dominan di sepanjang wilayah barat selatan Aceh, maka Tgk. Haji Muhammad Hasan Krueng Kalee memiliki murid dominan di sepanjang pantai utara timur Aceh. Kedua lokomotif mazhab Shafi'i di Aceh ini memiliki persamaan dan perbedaan, di antara perbedaannya adalah jika Tgk. Syekh Muda Waly dalam tarekat mengambil Tarekat Naqsyabandi, maka Tgk. Haji Muhammad Hasan Krueng Kalee mengambil Tarekat Hadadiyyah (Razali, dkk, 2010: 72-73).

Teungku Haji Muhammad Hasan Krueng Kalee lahir pada tanggal 13 Rajab 1303 Hijriyah (18 April 1886 M). Dilahirkan di Gampong Langgoe Meunasah Keutumbu di Pidie. Ayah beliau adalah Tgk. Haji Muhammad Hanafiah bin Tgk. Syekh Abbas, dikenal dengan teungku Haji Muda Krueng Kalee yang juga sahabat dekat Teungku Syekh Muhammad Saman Tiro (Teungku Chik Di Tiro) serta sahabat Teungku Chik Pante Geulima di Meureudu - Sigli. Tgk. Haji Muhammad Hasan Krueng Kalee mengajarkan kitab-kitab fikih Shafi'iyyah di dayahnya, kitab-kitab yang diajarkan meliputi Matan Taqrib, Syarah Fathul Qarib oleh alBajuri, Matan Minhaj, Iqna' oleh Khatib al-Syarbaini, al-Mahalli, Qalyubi, Fathul Wahhab, dan kitab Tuhfah yang diajarkan untuk santri khusus.

Murid-murid beliau yang cukup terkenal dan telah mendirikan berbagai pesantren Shafi'iyyah di Aceh adalah sebagai berikut: 1) Tgk. Syekh Marhaban di Banda Aceh; 2) Tgk. Syekh H. Muhammad Ghazali di Aceh Besar; 3) Tgk. H. Abdul Wahab Seulimum; 4) Tgk. H. Idris Lamnyong (abu Lamnyong) ayah dari almarhum Prof. Dr. Tgk. H. Sofwan idris; Tgk. Ibrahim Payed, 6) Tgk. Ali al-Su’udi; 7) Tgk. Abu Bakar Lampineung; 8) Tgk. Hasan Keubok mantan qadhi XXVI Mukim di Aceh Besar; 9; Tgk. Abdul Hamid; 10)Tgk. Abdul Aziz; 11) Tgk. H. Abdullah Lhok Kaju (Abu Sigli); 12) Tgk. Abdul Jalil Cot Plieng Bayu (Pimpinan Dayah al-Huda); 13) Tgk. H. Yusuf Kruet Lintang (mantan ketua MUI Aceh Timur); 14) Tgk. H. Kolononel Muhammad Nurdin; 15) Tgk. Abdurrahman Takengon (Teungku Gayo); 16.) Tgk. Syekhmud Blang Pidie, 17) Tgk. Abdurrahman Teunom; 18) Tgk. Abdullah Tapak Tuan, dll. 


\section{Dinamika mazhab Shafi'i dengan cara Aceh: Studi tentang praktik mazhab...(Zulkarnain )}

\section{Penutup}

Demikian gambaran dua lokomotif besar mazhab Shafi'i di Aceh yang masing-masing memiliki batas pengaruh yang besar berdasarkan geografis yang ada di Aceh, yaitu Barat Selatan dan Utara Timur. Apabila dilihat dari sisi lain yaitu dinamika politik ada ulamaulama Shafi'iyyah di Aceh yang merujuk kepada MUNA (Majelis Ulama Nanggroe Aceh) ada yang merujuk pada MPU (Majelis Permusyawaratan Ulama) Aceh, ada yang merujuk pada HUDA (Himpunan Ulama Dayah Aceh), dan ada juga yang merujuk pada RUDA (Rabithah Ulama Dayah Aceh).

\section{Daftar Pustaka}

Abbas, Sirajuddin. Sejarah dan Keagungan Madzhab Syafi’i. Jakarta: Pustaka Tarbiyah, 2003. Al-Asqalami, Ibn Hajar. Ma'âli Al-Ta’sîs fi Manâqib Ibnu Idris (Mesir: Al-Amiriyah, 1982.

Al-Nawawi, Muhyidin Abi Zakaria Yahya bin Syaraf. Al-Azkar al-Munkhamibah min Kalâm Sayyid al-Abrâr. Beirut: Dar al-Fikr, 1983.

Al-Nawawi, Muhyidin Abi Zakaria Yahya bin Syaraf. Ttp. Min\%âj al-lalibîn wa Umdah alMuftin. Singapura, Al-Haramayn, 1984.

Al-Nawawi. Muhyidin Abi Zakaria Yahya bin Syaraf. Tahdhîb Al-Asma’ Wa Lughat, Jilid I. Mesir: Muniriyah, 1984.

Al-Subkhi, Tajuddin. labaqat Al-Shafi'iyyah Al-Kubra, Jilid I. Mesir: Isa Baabil Halabi, 1964.

Al-Shafi'i, Abu Abdillah Muhammad Idris. Al-Umm Ma'a Mukhtacar Al-Muzani, Jilid I. Beirut: Darul Fikri, 1980.

Al-Syiraazi, Abu Ishaq. Al-Tanbi\% fi al-Fiqh Al-Shafi'i. Beirut: 'Alam al-Kutub, 1983.

Al-Zahabi. 1990. Siyâr A'lam Nubala, Jilid X. Beirut: Mu'assasah Al-Risalah.

Fahmi, Mutiara dkk. Teungku Haji Muhammad Hasan Krueng Kalee. Banda Aceh: Yayasan Darul Ihsan, 2010.

Feiilland, Ande. Islam et Arme Dans L Indonesi Contempolaine. (terj.) Lesmana NU vis Negara. Yogyakarta: LkiS, 1991.

Hamka. Sejarah Umat Islam. Singapura: Pustaka Nasional, 1994.

Hasjmy, A. Ulama Aceh Mujahid Pejuang Kemerdekaan dan Pembangun Tamadun Bangsa. Jakarta: Bulan Bintang, 1997.

Khalikan, Ibn. Wafayat al-A'yan wa Anba' Abna' Al-Zaman. Beirut: Darul Tsaqafah, 1971.

Latyif, Jamil. Kedudukan dan Kekuasaan Peradilan Agama di Indonesia. Jakarta, Bulan Bintang, 1983. 
ljtihad, Jurnal Wacana Hukum Islam dan Kemanusiaan, Volume 15, No. 2, Desember 2015: 159-176

Manshur, Majdi ibn. Tafsîr Imâm Al-Shafi’i. Beirut: Darul Kutub Al-Ilariyah, 1995.

Mutahhar, Abdul Hadi. Pengaruh Mą̧hab Syafii di Asia Tenggara. Semarang, aneka Ilmu, 2003.

Nasution, Lahmuddin. Pembaruan Hukum Islam dalam Madz̧ab Syafi'i. Bandung: Remaja Rosda Karya, 2001.

Syatta, Sayid Abu Bakar. \$athiyah I'anat al-lalibin. Bandung: Syirkah Ma'arif, Ttp.

Syirbasi, Ahmad. Al-Aimmat al-Arba'ah. Kairo: Darul Hilal, 1981. 